\title{
Restructuring of CDC and Labour-Related CSR: Ambivalent Application of CSR in A State-Owned Enterprise.
}

\author{
Clovis Ebot Obale1*, Valentine Okale Dang2* \\ 1Ph.D. Candidate, University of Yaounde I, Faculty of Arts, letters and Social Sciences, P.O. Box 755 Yaoundé, \\ Cameroon, Department of Geography, Cameroon \\ 2Deputy Director General, Credit Mutuel D'investissement du Cameroun (CREMINCAM), P.O box 3163 \\ Yaounde, Messa.
}

\begin{abstract}
*Corresponding Authors: Clovis Ebot Obale, Ph.D. Candidate, University of Yaounde I, Faculty of Arts, letters and Social Sciences, P.O. Box 755 Yaoundé, Cameroon, Department of Geography, Cameroon and Valentine Okale Dang, Deputy Director General, Credit Mutuel D'investissement du Cameroun (CREMINCAM), P.O box 3163 Yaounde, Messa.
\end{abstract}

\begin{abstract}
Corporate Social Responsibility (CSR) practices in state-owned enterprises in Cameroon have been growing rapidly in recent decades due to pressure from civil societies and international organizations for companies to prove compliance and benefit to localities where they operate. The management of the Cameroon Development Corporation $(C D C)$ had to reduce the budget allocated for labour-related CSR activities during the crisis due to financial constraints and ignorance, since most SOEs view CSR initiatives as philanthropy rather than a solution to their crisis. They do not understand that corporate social responsibility projects can ensure productivity and ensure competitiveness. The researcher employed a phenomenological research design that entailed conducting in-depth interviews with 30 CDC workers alongside a documentary review of privatization to assess CDC's-CSR level of commitment during restructuring and its implication on working conditions and performance. This paper also asserts that the restructuring of the CDC has not been socially responsible. It gave management the leeway to implement austerity measures that have had negative consequences on all labour-related CSR, thereby undermining CSR initiatives in the company. CDC is now the scene of frequent strike actions due to poor working conditions and misery. CSR in the CDC is a paradox. CDC should invest more in CSR since there is a positive correlation between CSR and employee engagement.
\end{abstract}

Key words: Corporate social responsibility, state owned enterprise, labour-related CSR, CDC and Cameroon

ABBREVIATIONS: CAMWATER: Cameroon Water Utilities Corporation, CDC: Cameroon Development Corporation, CDCWU: Cameroon Development Corporation Workers Union, CIMENCAM: Cimenteries du Cameroun, CSR: Corporate Social Responsibility, DISAWOFA: Divisional Syndicate of Agricultural Workers in Fako, ENEO: Energy of Cameroon, FAWU: Fako Workers Union, FCFA: Franc de la Communauté Financière de l'Afrique, MTN: Mobile Telephone Network, SGBC: Société Générale des Banques du Cameroun, SONARA: Société Nationale de Raffinage, SODECOTON: Société de Développement du Coton

\section{INTRODUCTION}

Corporate social responsibility, also called corporate citizenship is a situation whereby companies incorporate social and environmental concerns in their business operations with the support of stakeholders on a voluntary basis (Reverte, 2009). The increased interest in CSR in recent decades stems from the increased attention stakeholders paid to corporations' behavior in today's society to ensure and maintain a good reputation about their enterprise in public. Global scandals about multinational companies point to the fact that irresponsible behavior has negative consequences on a firm's reputation as well as a responsible behavior can also bring enormous benefits to the corporation (UN Global Compact-Accenture, 2010). CSR has witnessed a gradual change in meaning and practice over the years. In the early 1960s, it was limited to philanthropy and later shifted to business-society relations (Lee, 2008). Corporate managers employ CSR as a strategy to promote and sustain socially responsible restructuring. CSR-driven approaches to socially responsible restructuring remain underexplored due to limited knowledge and literature about corporate actions that form part of a socially 
responsible approach to restructuring (European Commission, 2008). The existing relationship between CSR and restructuring in Africa has not been fully explored within business ethics literature over the last decade, particularly on issues about mass layoffs, health and safety at work, decent working conditions, a violation of workers and labour union rights. The focus of many SOE's-CSR activities in sub-Saharan Africa in recent decades has been on the environment and finance rather than on the working conditions of employees (Ester, 2007).

Corporate social responsibility in Cameroon has received much attention from scholars in recent decades since it is a country marked by conflicts, environmental degradation, and poverty, thus giving the corporate sector the ethical dilemma of focusing on their social responsibilities in accordance with local needs while staying globally competitive (Visser, 2006b). Large multinational companies and SOEs in the country are under pressure from international organizations and civil societies to make CSR projects a priority in their annual budgets. However, although they are several publications on CSR in developing countries, there is the realization that Cameroon is much less researched than other countries in Africa in this domain. SOEs in Cameroon got engaged in CSR activities since the early 1960s, though it was performed as philanthropy, thus the raison d'etre why most SOE's do not have well-stated CSR policies. What's more, there has also been a marked increase in multinational companies in Cameroon since the early 1990s because of the privatization of several state-owned enterprises, which is gradually changing the CSR landscape in the country from share benevolence to a corporate commitment thus making it an integral component of a company's policy. SOE's in the country are noted for promoting CSR activities through philanthropic projects such as health, education and poverty reduction and engage in CSR activities to create employment and generate income. Examples of such SOE's are ENEO, SONARA, SODECOTON, CIMENCAM and MTN (Ndzi Ernestine, 2016).

In the CDC, CSR policies were geared toward the welfare of workers, which also had a positive impact on the neighboring communities. The CDC took it as a responsibility to provide pipe borne water, electricity, medical and recreational facilities alongside housing to her employees, which were also left open to the public, particularly villages that border their plantations. The CDC also sponsors cultural festivals in the region, offers scholarships and provides vacation jobs to students. The restructuring of the CDC began in the late 1980s due to the economic crisis and pressure from international financial institutions such as IMF and World Bank for countries to embrace-free market principles and liberalize their economies. The restructuring of the CDC that started with rehabilitation and later privatization had a negative impact on the working and living conditions of the workers. It witnessed a drastic reduction in social amenities that were provided by the CDC to workers free of charge, long working hours, low incentives and high pro-rata leading to low monthly wages. Workers that were layoff because of this restructuring left without being accorded their full benefits. It also had a devastating impact on the Workers Trade Union (FAWU) since its powers were curbed making it difficult for it to protect the rights of employees and union leaders became targets of intimidation and persecution. Health and safety at work became deplorable as the CDC was unable to provide working equipment's to her employees. The regular discharge of untreated waste into nearby streams and the aerial spraying of insecticides is a major threat to the health of workers and their families. The houses that the CDC provides to her employees are small in sizes (one or two bed room flats), overcrowded and dilapidated with poor ventilation. The dirty environment and few pit latrines, makes this camp settlements a fertile breeding ground for mosquitoes that cause malaria.

\section{ObJectives Of THE STUdy}

This study seeks to make an assessment of CDC's-labour-related CSR level of commitment during restructuring. It also provides reasons why there was a drastic cut in labour related CSR budget compared to the other CSR and the implications of these measures on working conditions and performance of workers.

\section{REVIEW OF RELATED LITERATURE}

The definition of CSR and its interpretation has gone through several challenges in recent decades. CSR, however, has no accepted definition of the term that adequately reflects its focus and level of corporate social practices (Matten and Moon, 2008, p. 405). CSR is a philosophy and a vision of the relationship existing between business and society requiring leadership to implement and sustain over 
time. It should be treated as an investment not a cost. It is a process of continuous improvement referred to as "caring capitalism" in contrast to "financial capitalism" (Palazzi et al., 1998). Research on the influence of CSR on customers, company's financial performance and environment has given preference over research on labour-related CSR that focuses on employees' perspective. The existence of this gap is astonishing when one tries to look at the contributions and sacrifices employees make for a company to succeed and having in mind that CSR implementation and its success depend on employee willingness to cooperate. Employees are the biggest and most influential of all stakeholders in a company (Hejjas et al., 2018). CSR plays a key role to attract talented workforce, increase commitment and encourage socially responsible behaviour. Empirical studies on CSR in both developed and developing countries have shown that companies that engage in CSR do have better performance than those that do not (Bauman \& Skitka, 2012). In several developing countries in SubSaharan Africa, governments lack funds to provide public goods and services at a desirable level due to corruption and resource constraints. It is also difficult to enforce regulations that will monitor the activities of companies due to institutional weaknesses and governance gaps (Margolis and Walsh, 2003).

Furthermore, employees are now more conscious of a company's responsibility toward society. Employees' attitudes and behavior influence their perceptions about company's social responsibility. The successful implementation of CSR activities depends more on employees' participation and support and so their participation in all CSR initiatives is indispensable. It is the responsibility of management to define employees' roles in the process. Companies are bound to achieve more benefits if it communicates its CSR strategies effectively with employees. The creation ofa cordial relationship between employees and company management needs using CSR policy as a strategic tool. CDC should invest more on labour-related CSR initiatives and communication to improve on the wellbeing of employees. CSR reports enable companies to inform stakeholders about the real condition of the company. Though CSR reports are tailored for external stakeholders, it can also be used to sensitize employees about CSR activities of the company. CSR is a strategic tool when creating a healthy relationship between employees and the company. The most important components of internal CSR dimension are investments in professional development, good working conditions, health and prevention of accidents during working hours and lastly a secure pension for workers when they retire (Damnjanović, 2019).

The study also asserts that most CSR activities in Cameroon are performed by large business enterprises through philanthropic projects such as health, education and poverty reduction programmes. They are several examples of private sector engagements in CSR initiatives that act as sources of income through job creation, particularly in rural areas. SOEs and private companies in the country, who are active in CSR activities, have been given the leeway by government to perform these projects as philanthropy not as an obligation. What's more, the constitution of Cameroon has no strategic framework or legislation governing CSR in Cameroon. In addition, large companies, such as SGBC, MTN and Orange-Cameroon have put in place several projects to improve the living conditions of people in rural areas. An example worth citing is the case of ENEO that has led to the development of the Massok-Songloulou and Pouma communities, thereby contributing to poverty reduction, although there is a complete lack of engagement by companies in the country about ISO 26000 standards. CSR activities are now increasingly aligned with core businesses and societal priorities with a budget to enable CSR activities to be strategically chosen in accordance with core business purposes, explicitly driven and anchored to the existing legislation and benchmark standards. Collaboration is being sought with government and global institutions to ensure that reporting becomes a common practice in all companies in the country (GIZ, 2013).

\subsection{Theoretical Framework}

This study uses institutional and the stakeholder theory as a lens to fully analyse CDC labour-related CSR activities during the restructuring of the CDC and its implications on the working conditions of workers.

\subsubsection{Institutional Theory}

The institutional theory asserts that a firm's behaviour is governed by its institutional environment or country where it operates alongside its constituents such as its social context, its activities and 
network of social relationships (Doshi \& Khokle, 2012). The prevailing institutions tend to bring uniformity in practice through these mechanisms, which are coercive, normative and mimetic. Coercive mechanisms are techniques that are used by existing institutions to bring pressure on a firm or industry for its activities to be in line with societal expectations. Alternatively, mimetic practices are peer pressure on companies to conform to certain established behaviours. In addition, normative practices look at the suitability of certain established behaviours (DiMaggio\& Powell, 2000). Institutional forces are drivers of agent's behaviour and act as a link to agent's beliefs about societal norms caused by internalization of norms or external pressure. In countries with a strong focus on CSR there is bound to exist high implicit CSR since CSR activities depend on existing legal structures of the country. Alternatively, in countries with strong social support for CSR with weak government regulations, there is bound to be high explicit CSR as companies would highlight their CSR activities. Institutional theory is suitable for explaining national-level differences in corporate governance. Institutional pressures not only drive CSR spending but also affect CSR policy. A review of CSR initiatives in the United States of America and in some European countries assert that measuring explicit CSR in terms of a company's donations and reporting is more prevalent in the USA than in most European countries (Matten \& Moon, 2008).

Institutional theory asserts that the interests of organizations are institutionally driven since organizational practices; including CSR that conforms to societal values and norms to regain legitimacy (Campbell, 2007, DiMaggio and Powell, 1983). The provision of public goods and services by companies alongside self-regulation should be conceptualized as institutional CSR. Recently, institutional theory has offered new insights into the drivers of CSR, showing that contextual factors in developing economies are different from the West and strongly influence how CSR is perceived and practiced (Aguilera et al., 2007). Countries in Africa, particularly Cameroon have a long tradition of philanthropy and distinct social structures that shape the behaviour of companies operating within its national territory. In such a context, CSR can be seen as implicitly driven since firms take it as a responsibility to respond to the prevailing societal values and norms. Inhabitants of neighbouring communities to the CDC have had high expectations that the CDC will fill the gap where governments fail to provide quality social amenities (Visser, 2009). Moreover, good examples also worth citing are the cases of local communities in Nigeria (Amaeshi et al., 2006) and Azerbaijan (Gulbrandsen and Moe, 2007), where oil companies in partnership with non-governmental organizations provide basic social amenities of high quality to local communities.

In addition, institutional processes of normative isomorphism are a situation whereby pressure is put on an organization to adopt voluntary activities and practices that are socially acceptable, which is in accordance with legitimacy theory that states that firms should engage in activities that adhere to societal norms. This study asserts that companies do not operate in isolation since they are embedded in the communities in which they operate (DiMaggio and Powel, 1983, Fernando and Lawrence, 2014). It is obvious that some firms decide to engage certain norms through their CSR practices that other companies follow are best described within institutional theory literature as mimetic isomorphism. In accordance with decoupling dimension of institutional theory, public goods that companies provide employees and neighbouring communities free of charge are not an integral part of the firm's main business activity. Empirical studies on CSR affirm that Corporations with weak financial performance do not act in socially responsible ways (Campbell, 2007).

\subsubsection{Stakeholder theory}

Stakeholder theory asserts that it is the social responsibility of companies to consider the interests of all parties affected by their actions in contrast to the shareholder view, which argues that only the' interests of shareholders are important. A firm's stakeholders are made up of the following individuals: employees, suppliers, customers, investors and governments, broadly defined it is composed of any group of people affected by the activities of the firm (Freeman, 1984). Helmig et al., (2016) has classified stakeholders into two main groups, which are primary and secondary stakeholders. Primary stakeholders are those who have a direct influence on the decision making of the firm and are indispensable for its survival. They are made up of the following: investors, employees, customers and the government. Secondary stakeholders are composed of the following: media and trade unions that have an indirect influence on the company (Clarkson, 1995). When companies are in financial crisis, they tend to prioritize their stakeholders according to instrumental 
and normative considerations (Jamali, 2008). In recent decades, scholars have advanced the stakeholder theory using two main perspectives that are the normative and descriptive perspectives. The former assumes that the legitimate interests of all stakeholders be taken into account by companies and thus stakeholder salience is less relevant, while on the other hand the descriptive perspective assumes that organizations identify which stakeholder interests are important, thus stakeholder salience is relevant. This study employs the descriptive perspective of stakeholder theory since the normative perspective has little explanatory power in a CSR context and the fact that the descriptive perspective can be used to explain drivers, processes and outcomes of CSR (Frynas \& Stephens, 2015; Frynas \& Yamahaki, 2016). Empirical studies on CSR conducted in the USA and in Germany affirm that stakeholder pressures impact CSR-related activities and decisions (Surroca et al., 2013)

\section{HYPOTHESIS}

$\mathrm{H} 1_{\mathrm{a}}$ : The management of the CDC greatly reduces the power and influence of the Fako Workers Union (FAWU), which makes it difficult to protect the rights of workers.

$\mathrm{H} 2_{\mathrm{a}}$ : The working conditions of CDC plantations are poor, and health and safety measures are rarely considered.

$\mathrm{H}_{\mathrm{a}}$ : The layoff of workers during the privatisation of the CDC was contrary to the principles of socially responsible restructuring because management failed to seek the consent of workers during the privatisation negotiations.

\section{MAterials And Methods}

\subsection{Study Area}

The CDC has plantations in the southwest, Littoral, West and North West regions of the country. Its plantations in the South West Region are between latitudes $4^{\circ} 4^{\prime \prime}$ and $402^{\prime \prime}$ north of the equator and longitudes $8^{\circ} 7^{\prime \prime}$ and $9^{\circ} 25^{\prime \prime}$ east of the Greenwich meridian. Its plantations in Fako Division have a boundary in the west with Nigeria, east by the Littoral Region and on the North by Meme and Ndian Divisions, respectively. Fako Division covers an estimated land surface area of about 2.057 kilometres square with a population of about 446,170 . Agriculture is the main economic activity of the inhabitants in this region with tomatoes, cassava, plantains and cocoyams as the main food crops. The CDC operates several plantations in Fako Division, such as the rubber, oil palm, tea and banana plantations. It has several rubber factories and palm oil mills in Mondoni and Lobe in the South West Region. These plantations are found in Fako-Division in areas such as; Tiko, Likomba, Tole, Idenau, Bota, Meanja and Ekona (Fongod et al., 2013).

\subsection{Methods and Techniques}

\subsubsection{Data Collection}

This study employs a qualitative phenomenological research design with purposeful sampling of participants. The phenomenological approach seeks to unravel how phenomena are perceived by peoplein a given area.It entails collecting in-depth information about labour-related CSRs (working and living conditions, layoffs, labour union activities and pension issues) and perceptions about the phenomenon using inductive qualitative methods that include discussions, interviews and participant observation (Moustakas, 1994).The collection of data entailed conducting in-depth interviews and focus group discussions with 30 workers drawn from four CDC camps in Fako Division, such as Likomba, Tiko, Mondoni and Tole, who have served with the CDC for more than ten years.The collection of data occurred in February-April, 2016 (first field visit) and later in October-November, 2016 (second field visit).However, this method of data collection was the most preferred because of its flexibility in eliciting detailed information from respondents in their own words, about their social world (Lofland and Lofland, 2006). The researcher also made extensive use of secondary materials (articles, published books, thesis and technical reports) dealing with CSR, the CDC and industrial restructuring in developing countries.

\subsubsection{Sampling Techniques of the Population}

The researcher employed purposive sampling as a guide in the selection of CDC workers from all four main sectors (banana, tea, palm and rubber) that was used in the study (Yin, 2003). The CDC operates 
several plantations in the southwest, Littoral, West and North West regions of the country. CDC was chosen because it has contributed immensely to the development of local communities in the southwest and northwest regions, it's a leading company in charitable activities, and is also the second employer in the country after the government. It is one of the largest SOEs in the country handed over to the government by colonial masters after independence in 1961. The CDC is a key player in the development of the South West Region and has supported local farmers and government in providing social amenities.

\subsubsection{Data Analysis}

The researcher employed the hermeneutic approach to assist in the interpretation of people's life experiences and meanings in a bid to develop a sound understanding of their world from an epistemological perspective, with the impression that knowledge is a social and subjective construct. The data gathered were rich accounts of people's realities, buttressed by descriptive statistical analysis. The organization of data collected entailed the continuous display and assembling of data involving the production of descriptive data in the form of tables, graphs and schematic diagrams. The data and information collected were organized into text. Institutional and stakeholder theories were used to guide this research inquiry and during the data analysis and interpretation exercise.

\section{Results}

\subsection{H1: The management of the CDC greatly reduces the power and influence of the Fako Workers Union (FAWU), which makes it difficult to protect the rights of workers.}

In July 1947, the Cameroon Development Corporation Workers' Union (CDCWU) was registered as a worker trade union on the registers of the newly formed CDC in accordance with the Nigerian Trade Union Ordinance of 1938. The CDCWU later became one of the largest workers' trade unions in West Africa with a membership of about 19,700 in 1952. The British Trusteeship Authority, which is the guardian of the property, supports the establishment of the union because it is considered a viable means of labour control in plantations. The labour department shoulders the responsibility of managing the company's labour affairs and has initiated an education program to educate union leaders on the sound management principles of union management and state-owned company union management. CDCWU leaders are taught by management during these seminars and workshops not to get involved in politics and to ensure that there should always be a peaceful dialogue when resolving disputes with management. It is strongly recommended that they promote bargaining and collective bargaining instead of resorting to labour bellicose that has a devastating impact on the CDC. Furthermore, in the early 1990s, with the liberalisation of multiparty in the country, trade union leaders particularly in Anglophone region, began clamouring for a return to the colonial model of trade union autonomy that existed when the corporation was managed by the colonial masters which they perceive as the best safeguard for protecting the interest of workers' ("the liberal-paternalistcolonial model advocated the absence of state intervention in industrial relations (laissez-faire)").Its focus is on free collective bargaining between trade union representatives and management representatives. The move made by the government and management toreplace the colonial model of autonomous trade unionism with a new model of state-controlled unionism in a bid to halt strike actions in CDC plantations in order to boost productivity resulted in the creation of the National Union of Cameroon Workers in February 1972 and later FAWU to replace CDCWU (Konings, 1993a).

The restoration of the CDC and subsequent privatization was met with strong resistance from the Fako Workers Union (FAWU), which firmly wanted to protect the rights of workers. It was for this reason that the government and the management of CDC decided to leave them out of the privatisation negotiating table. The absence of FAWU from the privatisation negotiations were clear indications that the plight of the workers was never taken into consideration during the privatisation deliberations. FAWU was responsible for all strike actions that were organised by the workers in the late 1980s and early 1990s. In addition, their uncompromising position made the CDC management to do everything they could to curb their powers and influence making it difficult for FAWU to operate smoothly. The CDC management decided to set up another union, called DISAWOFA, to disrupt FAWU's activities. The study also asserts that CDC management master minded the transfer of some 
workers from FAWU to DISAWOFA without their consent. What's more, the study also asserts that CDC management master minded the transfer of some workers from FAWU to DISAWOFA without their consent. This means that $1 \%$ deducted from the basic salary should be transferred to the DISAWOFA account instead of the FAWU account to weaken the influence of FAWU. The management of the CDC uses discrimination and persecution as a means to offset FAWU's disruptive activities, which are considered to be detrimental to the company's growth. As well, class segregation is common characteristics in all CDC estates, evident in the form of separate labour clubs for upper managers, lower managers and general labourers, and there is also a separate ward for management and labourers in all the CDC hospitals.

Furthermore, failure to bribe the supervisor can also lead to discrimination at the workplace. According to worker's testimonies, supervisors use promotions and pro-rata payments as a pressure tool for bribes. Workers reported that in order to remain in good terms with their supervisors, "you have to create a cordial relationship with your supervisor." You have to be kind to him". More than $95 \%$ of the plantation workers interviewed testified that: "workers who refuse to collaborate are sent to work where there are less fruits to harvest or might not be recommended for promotion". Cameroon's Labour Law provides for the right to be free from discrimination. Nevertheless, the interviewees assert that plantation workers are not completely free from discrimination. A number of respondents $21.3 \%$ reported that they have experienced discrimination. Some workers are favoured over others by management due to several reasons, which are: gender $23 \%$, age $14.2 \%$, political opinion $10.9 \%$, religious beliefs $9.3 \%$, and participation in union activities $25.1 \%$. The Cameroon Labour Code sets out the right to freedom from discrimination. Nevertheless the interviewees assert that plantation workers are not completely free from discrimination. A number of respondents $21.3 \%$ reported that they have experienced discrimination. Some workers are favoured over others by management due to several reasons, which are: gender $23 \%$, age $14.2 \%$, political opinion $10.9 \%$, religious beliefs $9.3 \%$, and participation in union activities $25.1 \%$. As well, more than $95 \%$ of the workers interviewed confirmed that they had witnessed several cases of discrimination due to tribalism and belonging to the FAWU Alliance. CDC workers in the focus group held on August 2016 reported they were being treated as "second-class citizens" by supervisors who are South Westerners. They also reported incidents of discrimination and intimidation related to the FAWU Group, and expressed concern that they would be fired if the CDC management was told that they had participated in the focus group. They are representatives of FAWU employees in the CDC. It is assumed that they belong to category 4, but because they are connected with FAWU, they still serve as general workers in category 2. The CDC also did not pay the huge sums deducted from workers' wages as membership dues in the FAWU Association's account for several years.

\section{2. $\mathrm{H2}$ a: The working conditions of CDC plantations are poor, and health and safety measures are rarely considered.}

The working conditions of the field staff in the CDC plantation are very poor. Although they put in a lot of energy, their income is not commensurate with their labour. While workers are doing their best to increase production, management and shareholders are benefiting from it (see Table6.1 and 6.2).

Table6.1. Salary scale of CDC workers (2014)

\begin{tabular}{|l|l|}
\hline CATEGORY OF WORKERS & DAILY WAGE/SALARY(FCFA) \\
\hline General labour & 135 \\
\hline Female workers & 118 \\
\hline Artisans & \\
\hline Class III & 320 \\
\hline Class II & 450 \\
\hline Class I & 615 \\
\hline Assistant Overseer & \\
\hline Male & 198 \\
\hline Female & 171 \\
\hline Headman & \\
\hline Male & 156 \\
\hline Female & 130 \\
\hline Time keepers & 173 \\
\hline Checkers & 145 \\
\hline
\end{tabular}

Source: CDC annual report sheet (2014) 
Restructuring of CDC and Labour-Related CSR: Ambivalent Application of CSR in A State-Owned Enterprise.

Table 6.1 presents the salary scale of CDC workers in 1995. The daily wage of a general labour stood at 135 FCFA per hour, Artisans class I was 615, assistant Overseer (male) 198 per hour and checkers 145 per hour respectively.

Table6.2. Monthly salaries for CDC workers in FCFA (2014)

\begin{tabular}{|l|l|l|l|l|l|l|}
\hline CATEGORY & \multicolumn{6}{l}{ GRADE(ECHELON) } \\
\hline & A & B & C & D & E & F \\
\hline I & 24069 & 24369 & 24681 & 24984 & 25289 & 25594 \\
\hline II & 25526 & 25911 & 26668 & 27199 & 27741 & 28278 \\
\hline III & 27659 & 29380 & 30476 & 31832 & 33182 & 34538 \\
\hline IV & 32781 & 37617 & 42465 & 47245 & 52160 & 57002 \\
\hline V & 54025 & 58760 & 63489 & 69534 & 72947 & 77664 \\
\hline VI & 74973 & 79535 & 84099 & 88660 & 93229 & 97792 \\
\hline VII & 80822 & 863207 & 91602 & 96987 & 102371 & 107767 \\
\hline VIII & 107767 & 119899 & 132005 & 144127 & 156255 & 168371 \\
\hline IX & 159483 & 170956 & 182457 & 193935 & 205414 & 215909 \\
\hline X & 178458 & 193145 & 207847 & 222538 & 237240 & 251931 \\
\hline XI & 251931 & 264520 & 277124 & 289723 & 302317 & 314917 \\
\hline XII & 314917 & 327516 & 340110 & 352698 & 365303 & 377902 \\
\hline
\end{tabular}

Source: CDC annual report sheet (2014)

Table 6.2displays the net monthly salary CDC workers collect at the end of the month. The computed salary depends on output of each worker category, pension contribution, bonuses, and duration in service, incentives and over time.

The sole objective of plantation agriculture from its inception is profit maximization at the detriment of the welfare of labourers. The female workers who cleaned up the warehouse secretly told the researcher that long hours of work prevented most of them from taking care of their children. The Delmonte staff responded to this again with the following words, "The working hours are long and tedious with low wages". Furthermore, $80 \%$ of the workers interviewed agreed that due to the nature of their job they have little time to rest or carry out household chores except on Sundays which is the only day a CDC worker can rest with his or her family or carry out cultural activities. As well, though workers should be automatically moved up the career ladder every 3 years, such a situation does not happen in principle except at the discretion of management. The study also observed that in the past ten years, most of the workers interviewed in the rubber and palm fields were not promoted, which is in violation of the Cameroonlabour law. Participants in the CDC focus group held on August 2016 by the researcher also commented on the possibility to bribe a supervisor to get promoted faster than others; "Supervisors have people whom they are familiar with because they give them bribe. It is this group of people who are shortlisted for promotion by management". Workers claim that they work very hard and expect their efforts to be rewarded, but they will eventually be frustrated by it.

It is also very frustrating to observe that several plantation workers in the palm and rubber department reported that they had worked with temporary contracts for more than 5 years before they had permanent contracts. This explains why some workers with 8 and 9 years of experience are currently classified as 1A or 1B. What's more, although most banana farms have water taps near their pack houses, over $80 \%$ of the workers agreed on the fact that they do not drink water in the plantations because "you get sick if you drink it". Instead, more than $95 \%$ of workers prefer to use water containers or plastic bottles provided by their employers to fetch water from their homes for use in the field. On the other hand, although toilets are available near all pack houses, workers don't have access to any of them, because they are locked by management and workers have to ask for the keys before using them. All field workers are entitled to protective equipment's such as rain boots, apron and gloves once a year. We saw workers working in the field without boots and gloves. Cleaners and field workers reported buying working equipment such as cleaning products, machetes, knives and filters; in order to work faster and avoid pro-rata, if they do not buy it themselves they will be unable to work efficiently and safely. The National Social Insurance covers workers between the hours of 6am and $6 \mathrm{pm}$. However, plantation workers often leave their homes at $4 \mathrm{am}$ and do not return until well past $6 \mathrm{pm}$. At the women's focus group meeting held in August 2016, women said that employers should provide them with risk allowances during the time they are not protected by social insurance, but this 
is not the case. It should be noted that workers who have accidents of any kind during field operations must go through arduous procedures to get the treatment they deserve. According to reports, there have been cases where workers died without receiving social insurance premiums.

The workers at the Tiko banana plantation are not confortable with the aerial spraying of chemicals on the farm. $80 \%$ of CDC workers said that they were never informed by management of the date and location of the spray. Only $20 \%$ of the workers agreed that they were informed of the spraying operation, especially in the rainy season, when spraying days are scarce and the decision is made at the last minute, but in the dry season, the aircraft should be fully informed when to spray, so workers know when not to enter the farm.CDC workers that find themselves in the field while the plane is spraying find it very difficult to run back to the pack house due to the distance and instead shelter under banana trees in the field, although the wind blows the chemical underneath the leaves and touch them where they are hiding. More than $70 \%$ of the workers also acknowledged the fact that if they run to the packing house to hide from the aerial spray, they would be paid pro-rata for that day or even sent home. CDC workers that find themselves in the field while the plane is spraying find it very difficult to run back to the pack house due to the distance and instead shelter under banana trees in the field, although the wind blows the chemical underneath the leaves and touch them where they are hiding. More than $70 \%$ of the workers also admitted that if they went to the packaging workshop to hide from the spray gun, they would be paid proportionally that day, and even be sent home.

However, there are many health problems associated with this chemical exposure, which are; skin rashes, irritation, and eye damage. 50\% of workers in the field and pack house clearly stated that when the chemical gets into their eyes "it burns like pepper", and that even if they're not in the field during the spraying, they still get in touch with the chemical when touching the banana leafs or during harvesting or deleafing. A worker said the chemical stains your skin in such a way that "you begin to look like a frog"; "before you wash it, it has already destroyed your skin" and "it peels the skin off your face". We have witnessed communities and CDC camps built close to the plantation where people suffer from chemical drift. Spraying contaminate streams and affect children playing outside. The study also asserts that pregnant women use plastic lids to apply fertilizers by hand and plastic gloves as their only protective equipment. These women told us they had been working for 8 hours in the tropical heat without a break. They were working alongside several male colleagues who were mixing large amounts of fertilizers without proper protective equipment. His boots were coloured because of the chemicals sprayed in the air that morning (see figure 6.3).

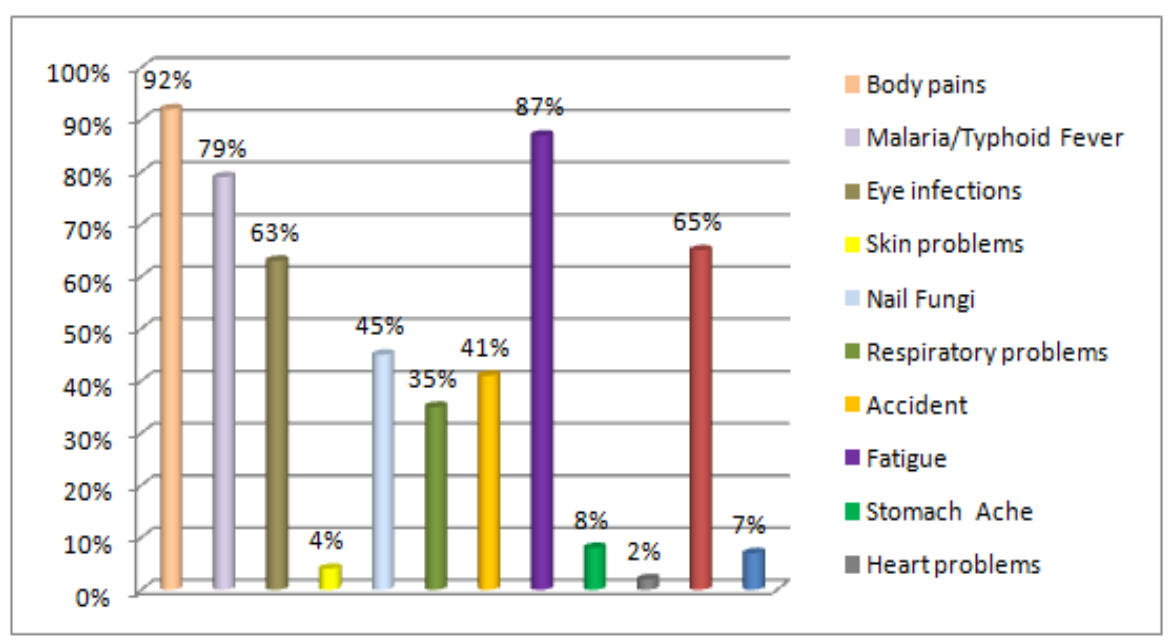

Figure6.1. Health problems of plantation workers

Source: Field survey (2016)

Figure 6.1 showcases different illnesses that affect CDC workers. The most common are body pains $92 \%$, typhoid and malaria $79 \%$ and eye infections $63 \%$.Such is the case with workers in the banana and rubber sectors, since they work for more than 10 hours with their hands in contact with water without gloves.

The CDC uses open trucks to transport workers from the camp to the field, which is often overcrowded and uncomfortable because workers have to stand for hours. About $90 \%$ of the workers 
interviewed responded that they use the company vehicles to reach and leave the plantations. More than $70 \%$ of workers who use company vehicles admit that they cannot board the company vehicle at least once a month. In such a situation, the only alternative is to take a taxi or motorbike, the cost of which can vary from 300 to 500 XAF. A second vehicle may appear later on, though uncertain and workers who do not want to risk arriving late and losing the day's pay end up taking a taxi. Workers also reported that they were injured by tools on the truck while trying to find a place in the vehicle. Amongst the workers who claimed to be always able to board on the vehicle, many admitted to wake up 2 hours earlier and get to the farm two hours before their working hour just to avoid the fighting and guarantee the day's salary. What's more, more than $95 \%$ of the workers also complained that vehicles don't always arrive on time during closing hours. More than $80 \%$ of the workers in the warehouse agreed to wait about 3 hours after the closing time to wait for the truck to take them home. The morning and evening hours that workers spend in plantations can be attributed to serious transportation problems, which are never included in their working hours. In our visit to the boarding stop we found out that workers have no problem boarding on the early vehicles, although it becomes very difficult to get a place in the rush hours since workers have to struggle hard to climb on the vehicle. Trucks transporting workers are often overcrowded, uncomfortable and poorly ventilated. These trucks have no seats, so in this crowded and dangerous situation, workers are forced to stand and carry work tools for many hours. According to reports, there was a road traffic accident involving CDC banana workers, killing all the workers on the ship along the axis of the Tiko-Douala highway.

\subsection{H3 $\mathrm{a}$ :The layoff of workers during the privatisation of the $\mathrm{CDC}$ was contrary to the principles of socially responsible restructuring because management failed to seek the consent of workers during the privatisation negotiations.}

CSR offers a guide on promoting socially responsible restructuring, though few companies and governments use it. Although CSR codes and frameworks are richly embedded with issues of labour and restructuring, financial and environmental issues continue to dominate CSR agendas in the corporate world. The global financial crisis that goes along with corporate restructuring offers an opportunity for a reconfiguration of CSR agendas around issues of employment and labour, as a means of addressing some of the negative socio-economic effects of restructuring and layoffs. What's more, socially responsible restructuring is capable of reducing the negative effects of the current global recession (Campbell, 2007).

Furthermore, attempts made by the government to privatize the CDC met stiff opposition from elites and civil society organizations in the southwest and northwest regions. This resistance came from the Fako Agricultural Workers Union (FAWU) representing and defends CDC workers' rights in Fako Division. FAWU argued that the CDC should not be privatized without the consent of the workers, since all plantation workers had made enormous sacrifices during the economic crisis to assist the corporation's recovery. However, to the dismay of some Anglophone elites the privatization of the CDC tea estate was announced in October 2002. It became clear that the CDC tea estates had been sold to a South African Consortium, Brobon Finex PTY Ltd. The privatization agreement that was reached between the Cameroonian government and Brobon Finex was based on the following terms: the government was to hand over $65 \%$ of its shares to Brobon Finex that, in turn, would sell $5 \%$ of its shares to its personnel. Moreover, Brobon Finex was also increased the area allocated for cultivating tea at Tole from 1,500 to 3,000 hectares in fifteen years and invested about FCFA 8 Billion over ten years. It would also reimburse all loans owed by the CDC tea sector which was estimated at 1.1 billion francs CFA. As well, CTE also agreed not to lay off workers but will instead improve existing health, educational and accommodation facilities and will continue to buy cash crops from local contract farmers. Lastly, in accordance with government's privatization policy, land would be excluded from the transaction (Obale, 2020).

In addition, the BLCC expressed dissatisfaction at the sale of the CDC tea estates without proper consultation with the landowners, despite the terms of previous deliberations between the committee and government on how privatization should be conducted. In March 2000, the labour union cautioned the government to respect the 1992 Labour Code that stipulates that workers should be consulted in the event of privatization about whether they would prefer to be paid off before negotiating new contracts with the CTE. However, due to the growing labour bellicose in the Tole Tea Estate, the government and the CDC management had not the courage to inform the Tole Tea 
estate workers of the planned privatization of the tea estates. The workers came to learn of it through the media. Furthermore, plantation workers being aware that privatization in Cameroon had led to retrenchments and deterioration in workers' working conditions were worried about their future, despite assurances that was given them by the CTE management during the signing of the privatization agreement that stipulated that the existing labour force and their conditions of service would be maintained (ibid).

Furthermore, the CTE management implemented a controversial reorganization program in December 2003 that went against the 1992 deregulated labour code. The absence of any state intervention in the matter can be attributed to the close links between top government officials and the management of CTE. The reorganization program had negative consequences for the welfare of plantation workers of the Tole tea estate. The CTE management implemented 50\% slash in workers' salaries and the withdrawal of any remaining allowances allocated to field workers. Furthermore, workers reacted negatively to this dramatic cut in their income by resorting to protracted strike action that began in January 2004. The CTE management used this illegal strike action as a pretext to dismiss 268 workers without paying all their benefits and immediately embarked on a recruitment program to recruit new workers from outside the Anglophone Region. Those dismissed were several staff representatives who were trying to protect the interest of plantation workers. Furthermore, note that the CTE's management vehemently refused to seek authorization for the dismissal of these workers from the Ministry of Labour as required by the labour code. However, the CTE management continued with her suppressive measures by transforming all permanent workers into casual and temporary workers. They also introduced a labour regime that became an increasing amount of despotic culminating to the suspension of the activities of the FAWU labour union on the Tole tea estate and by passing staff representatives when taking major decisions of the company (Konings, 1993a).

Furthermore, the workers being disappointed with these measures continued with their strike action until the 5th of February 2004 when the Minister of Labour intervened. Following the outcome of this mediation, it became evident that management was unwilling to respect the terms of this negotiation, which stipulated that the CTE management should refrain from wrongful terminations of contracts and paying low wages to her employees. In defiance of the above-mentioned clauses, the CTE continued with her plan to further make working conditions bad for her employees. The daily task for tea pluckers was increased from $32 \mathrm{~kg}$ in the slack season to $45 \mathrm{~kg}$ in the peak season. Furthermore, workers became outraged by this decision and so decided to boycott work for several weeks without permission. The CTE management reacted by announcing an additional cut in wages for workers. Given these developments, the living and working conditions on the Tole tea estate became so deplorable that workers do not bear and so they started complaining that the takeover of the tea estate by Brobon Finex was the beginning of modern slavery in Fako Division. However, to address this deadlock, the Minister of Labour and Social Security organized a crisis meeting in Buea in April and compromised with both parties agreeing that all accrued benefits should be paid out within three months. A month later, all the workers who had been paid off forcibly left the Tole Tea Estate with some returning to their villages of origin. Those who still wanted to work had to reapply as new workers and engage in new terms of contract (ibid).

\section{DISCUSSION}

The study asserts that CDC labour-related CSR is a paradox owing to ignorance, poor governance and financial constraints due to the economic crisis that witnessed a suspension of government subsidies to SOEs in the country. CDC employed drastic austerity measures in a bid to rehabilitate and restructure the company. CDC management and the labour union agreed to increase the working hours, reduce salaries, institute compulsory savings and cut-off all fringe benefits. CDC management went ahead to privatise and lay off workers without the consent of the labour union. Workers also suffer from discrimination, poor disposal of toxic waste from industries, aerial spraying of chemicals during working hours, poor housing conditions and low wages. Workers were layoff without paying their benefits after serving the corporation for more than 25 years. CDC decided to reduce the power of trade unions, making it difficult for workers' rights to be protected. Union members and staff have become targets of discrimination and persecution. Workers on their part have resorted to labour bellicose to make their choices heard. Workers organized several strikes without the consent of the union, disrupting company activities and negatively affecting productivity and annual income. 
However, pressure from international non-governmental organizations and labour unions has caused the CDC to reconsider its policies on workers. Several modern houses have been constructed to accommodate workers and their families and dilapidated buildings have been renovated and given a new look. The management also organized a number of workshops and seminars to improve the skills of its workers while preparing for future promotions. The CDC has also adopted a decoupling approach to corporate social responsibility to improve its public image. Government ministries such as the Ministry of Labour and Social Insurance, Agriculture and Rural Development, Ministry of Environment and Nature Protection and the Ministry of Finance, saddled with the responsibility to monitor the activities of SOE's in the country have failed to curb the activities of the CDC that have negative consequences on workers and the environment(CDC does not respect the basic minimum wage for agricultural workers and its activities do not comply with environmental norms)because of its ownership status as a SOE and its contribution to national development.

\section{DETERMINANTS OF CSR}

CSR is a multi-dimensional construct with different determinant characteristics such as: firm, corporate governance and institutional characteristics (Reverte, 2009).

\subsection{Firm Characteristics}

Empirical studies have shown that firm characteristics such as size, profitability and investments in R\&D affect a firm's level of CSR engagement (Gamerschlag et al., 2011). A company's, size also determines its level of engagement in CSR activities. The legitimacy theory argues that larger corporations are more likely to invest in CSR initiatives because of pressure from civil societies and external stake holders that act as a check on the activities of companies (Brammer \& Millington, 2008). As well, firms that make huge profits are often the first to engage more in CSR initiatives since they use self-regulating mechanisms to portray a positive image about their activities to the public and also to endorse its legitimacy. Moreover, leverage is also a major determinant that affects a company's level of CSR engagement. The less debt owed to the company, the more revenue it will set aside for corporate social responsibility activities. Firms that invest more in R\&D will also engage more in CSR activities through innovative processes or products (Hull \& Rothenberg, 2008). The $\mathrm{CDC}$ is the largest agro-industrial complex, and the second largest employer in the country. It invested a lot of money in research and development before the economic crisis of the late 1980s (when the debt burden was low). The above argument is sufficient to explain why CDC is actively involved in charity projects that benefit not only her employees, but also the communities surrounding these plantations. Due to budget constraints and ignorance, the arrival of the economic crisis marked a turning point in CDC policies and corporate social responsibility methods. Workers have witnessed drastic reductions in incentives and fringe benefits, drastic cuts in wages, longer working hours, and the high cost of social amenities that CDC previously provided to them for free. Since the CDC is still their main source of income, CDC workers are also deprived of a fixed salary for several months, which makes their lives miserable. The CDC also reduced its R\&D budget in a bid to pay off its huge internal and external debts, since the government was no longer able to provide subsidies to SOEs due to the economic crisis.

\subsection{Corporate Governance Characteristics}

In this study, the focus will be on aspects such as the type of ownership, ownership concentration and board members as possible determinants of CSR. Gamerschlag et al. (2010) assert that the concentration of ownership of a company is an important determinant of CSR. They also confirmed that the degree of ownership concentration will affect the company's CSR participation. Compared with companies with dispersed shares, companies with a high proportion of shareholders holding a large number of existing shares tend to participate more in corporate social responsibility activities (Gamerschlag et al., 2010). In addition, companies with more diversified shareholder identities have a higher level of CSR participation than companies with less diversified shareholder identities. Moreover, board diversity is also a determinant of CSR and has a positive effect on a firm's social performance. Diversification of the board of directors is desirable because it helps to improve the company's customer base and enable it to compete effectively on a global scale (Harfsi \& Turgut, 2013).

Before and after the privatization, the government has been a major shareholder of CDC, holding more than $70 \%$ of the shares. It's the responsibility of the government to appoint board members who 
are members of the ruling CPDM party who adhere strictly to party discipline and not the interest of the nation. The diversity of the CDC board of directors is very weak, because the members are from the ruling CPDM party, and they impress its political father rather than the country. Ordnance no 39 (1946), which is the foundation of CDC philanthropic policy stipulates that the corporation should not focus exclusively on capital accumulation, without allocating $10 \%$ of its profits to the social welfare of her workers' (Epale 1985). The above argument proves why the CDC invests most of its profits in social welfare programs, such as the construction of schools, hospitals and shops managed by cooperatives. However, after the economic crisis, CDC management decided to cancel many of these services in order to increase capital accumulation and repay its debts because the government was unable to provide subsidies.

\subsection{Industry or Institutional Characteristics}

Industry and institutional factors also play a key role as determinants of corporate social responsibility in the industry. Empirical studies have shown that a company's core activity also acts as a driver for that company's level of CSR engagement. Companies active in environmentally sensitive industries (such as mining and agro-industry) tend to participate more in corporate social responsibility activities than companies not engaged in the industry. The media is a key player in mobilizing environmental interest groups and has become a part of the institution building process, thus shaping norms and making CSR practices legitimate since higher levels of media exposure lead to higher levels of CSR engagement (Reverte, 2009). In addition, the institutional determinants of corporate social responsibility, such as the company's economic dependence on the country of origin of the parent company, and the company's exposure to countries that implement strict corporate social responsibility policies, often affect its degree of corporate social responsibility participation. There is a positive correlation between the power of corporate social responsibility institutions that resonate in the headquarters of multinational companies and stricter corporate social responsibility policies, and corporate social responsibility has been adopted in the countries/regions where they operate (Marano \& Kostova, 2016).

Primary and secondary stakeholders can also influence a firm's decision to engage in CSR activities; especially non-governmental organizations such as Greenpeace and Oxfam that have a significant influence on how CSR practices are performed in developing countries (Park \& Ghauri, 2015). CDC engagement in the environmental dimension of CSR is weak despite her activities that have a negative impact on the environment and on the health of employees. The CDC does not have a laid out environmental management plan (not ISO14001 certified) and does not respect national environmental regulations. Waste from oil and rubber plants is poorly treated before disposal into nearby streams flowing through the plantation, which are health hazards to workers and nearby communities. CDC waste treatment is poor due to the absence of a waste treatment plant. Wastes from all CDC mills are discharged into streams close to these mills, regardless of the health and safety of the workers. It is common to see women applying fertilizer in these plantations without protective equipment's. The aerial spraying of crops by CDC management is performed without the consent of workers putting their lives and those of their families in danger. The CDC did not use ISO 26000 to review and plan its social responsibility strategy. These are enough justifications to explain why its CSR initiatives are a paradox when looked at from the following aspects: human rights, labour practices, environmental protection and retrenchment.

\section{EFFECTS OF CSR}

Empirical studies on CSR in developed and developing countries alike have shown that engaging in CSR has enormous benefits for a company. Proponents of social identity and signalling theories argue that engaging in CSR activities leads to employee motivation and retention, while that of the stakeholder theory asserts that engaging in CSR initiatives will ensure risk reduction and those of the resource-based view theory affirm that engaging in CSR leads to improvement in reputation and access to capital that all culminates to an increase in future financial performance (Story et al., 2016).Firms with high CSR ratings are considered more attractive to employees than firms with low ratings. Companies with high CSR ratings will attract the recruitment of employees of high quality, while companies with bad reputation face recruitment problems that can be better explained by signalling and identity theories (Greening and Turban, 2000). Employees will need accurate information about an employer before accepting an employment offer. In a situation where such vital 
information is absent, employees look at the characteristics of the firm to know the type of firm. CSR attributes act as a signal to employees about the norms and values of a firm. Employees are willing to work for a company that has a positive reputation than with firms that have a bad reputation (Backhaus et al., 2002). CSR has a strong effect on firms' commitment and intangible benefits of engaging in CSR are increased employee loyalty, morale and job satisfaction (Hopkins, 2003). The CDC has a low CSR rating in the country. People in the Anglophone regions of the country are not willing to work with the CDC because of the tedious nature of work in the plantation. They go in search of employment in the CDC as a last resort. Jobs at the management level are difficult to get since politicians use it to appease their girlfriends and political allies. The recruitment of workers at the management level is not based on merit but on tribal, social ties and political lines. The low productivity and revenue of the corporation is because of the existence of an unqualified management.

Research on CSR and the activities of multinational companies in developing countries asserts that CSR help firms to reduce risks. Engaging in CSR creates moral capital on behalf of stakeholders that act as insurance protection when negative events occur (Godfrey et al., 2009). Harjoto and Laksama (2016) in their study of optimal risk levels in firms found that stronger CSR performance is associated with smaller deviations from optimal risk-taking levels. They also assert that CSR has a positive impact on a firm's value. CSR performance is positively associated with a firm's value since CSR reduces risk taking (Harjoto \& Laksama, 2016). As well, the resource-based approach of firms affirms that reputation is a resource that offers firms a competitive advantage and informing stakeholders about the attractiveness of the firm, who becomes willing to contract with it. There exists a positive relationship between a company's reputation and financial performance. The CDC has a negative reputation internationally due to its low CSR ratings, reasons why very few investors showed interest when it was advertised on the British stock exchange. The government continues to be the main shareholder holding more than $70 \%$ of the shares (Brammer \& Millington, 2008). CSR indirectly promotes a firm's performance through corporate reputation. While a positive reputation gives credibility to an organization, a bad reputation discredits the image of a firm in public. CSR influences a firm's financial performance and reputation eventually (Lin-Hi \& Blumberg, 2016). In accordance with the resource-based approach, reputations are critical because of their potential for value creation and intangible character that makes replication by competing firms difficult (Barney and Clark, 2007). As well, a firm's ability to access capital is a function of its level of CSR initiatives, which is its ability to attract investments that enhance financial performance. Investors tend to invest funds in companies with higher corporate social responsibility ratings, because companies with good corporate social responsibility performance face much lower capital constraints. Research has shown that stakeholder engagement and transparency in CSR initiatives are important drivers in reducing capital constraints (Cheng et al., 2014). The participation of corporate social responsibility benefits companies because it helps reduce the cost of equity capital (El Ghoul et al., 2011).

\section{CSR DECOUPLING}

According to Banerjee (2008), "CSR reports come often in glossy forms that do not expose the grim realities that lie behind them." When a company's CSR practices do not reflect the content promoted and described in its CSR report, CSR will be decoupled (Bice, 2013). This phenomenon is common with organizations that publish CSR reports annually and makes it difficult to deduce what the actual CSR activities are from their reports (Skovgaard, 2012). Pressure from civil societies and international organizations for companies to engage in CSR have led to CSR decoupling behaviour in which CSR reports spread disinformation in order to present an environmentally friendly image in public (Visser, 2014). CSR decoupling involves processing CSR reports. It allows organizations to manage their reputations and hide undesirable corporate activities (Lyon and Montgomery, 2013).A good example of CSR decoupling or green washing in CSR reports occurred during COP21 in Paris in which six hundred fake advertisements were uncovered portraying the unethical behaviour of most COP21 sponsors. COP21 sponsors did not disclose their true carbon footprint and CO2 emissions (Petit Jean \& Du Roy, 2015). It was clear that COP21 sponsors were concerned with building a corporate sustainability image through publicity by sponsoring climate variability issues, while their CSR practices were contrary to their rhetoric's. The series of protests during COP21 are an eye opener for genuine CSR reports in which CSR decoupling does not happen. Researchers should continue to explore CSR reports in the context of CSR decoupling (Lyon \& Montgomery, 2013). 
The CDC uses toxic chemicals such as nematicides (Dithane, Counter 15G, Mocap and Furadan) to kill borers and weevils. These borers and weevils can damage the roots of bananas and are toxic to bananas. A worker interviewed at the CDC banana plantation said: "inhaling vapour or getting in contact with nematicides cause cramps, vomiting and sterility in men". The chemicals are toxic and the CDC is not interested in the welfare of labourers". A medical doctor working for the CDC said "agro-chemicals used by the CDC are toxic. They cause damage to enzymes in the human body that is why we perform routine enzyme tests on workers. Aerial spraying is conducted when workers are in the field. No warning will be issued before aerial spraying”. As well, due to this aerial spraying the Sigatoka disease affects women who are deleafing bananas in these plantations. Due to poor protection, the fruit harvesting men and nearby communities have also become victims. The wastewater from the CDC rubber and palm oil plants is discharged into nearby streams without treatment, creating an unhealthy environment for humans. The CDC camps or settlements are unhealthy slums that are crowded with few pit toilets. The worker-toilet ratio is 1:70.

Furthermore, the Ministry of Environment and Nature Protection has failed on her part to monitor the activities of the CDC in order to ensure environmental compliance making matters worse for workers and local residents. Workers work long hours with low wages and incentives. The standard of living of CDC workers is low. They live in a vicious circle of poverty. A worker testified that "Due to our low salaries due to pro-rata payments we are forced to borrow and engage in other farm activities to augment our incomes. Our life is miserable." The annual CSR reports of the CDC do not reflect the actual situation of the company. Its mission is to portray a positive image of the company to its stakeholders. CDC workers are the lowest paid in the country, living in abject poverty with a low standard of living. CDC camp houses are out-dated and dilapidated since they were constructed before 1945.To date, only few modern houses have been constructed by the CDC to accommodate workers. These houses are crowded (1-2 bedroom per worker) since most of the workers have large families. The CDC regularly updates its corporate social responsibility report every year to provide stakeholders with a positive impression of company activities, which does not reflect the actual situation. Efforts made by the workers labour union (FAWU) for the salaries of workers to be increased have met stiff resistance from management. The CDC's mission is to make profits and not to improve the welfare of workers.

\section{CONCLUSION}

Corporate social responsibility is a new thing in Cameroon, because many companies do not have appropriate CSR policies or departments that manage corporate social responsibility issues. Cameroon has been noted as one of those countries in Africa where companies promote CSR practices through philanthropic projects in health, education and poverty reduction. The influx of foreign investors in the country owing to the privatization of SOEs in the early 1990s has witnessed an increase in CSR activities that has been initiated by companies as corporate benevolence, although some of the firms do not have written CSR policies. This study asserts that due to ignorance, poor governance, and financial constraints, CDC's labour-related CSR practices are not efficient. Further, although the CDC managesmany hospitals, recreational and educational facilities that serve workers alongside neighbouring communities, CDC's labour-related CSR rating remains low owing to factors such as: low agricultural minimum wage, long working hours, poor health and safety measures during working hours, poor housing conditions for workers, poor insurance plans, irregular monthly wages, and low incentives. CDC workers have one of the lowest standards of living in the country and live in a vicious circle of poverty. Although, some non-governmental organizations such as Banana Link and FAWU have exerted pressure on CDC management to review its policies on working conditions of employees, little has been done to ameliorate the situation. As well, laid-off workers have filed several complaints with the Department of Labour and the High Court in Buea against CDC's illegal dismissal which is still pending judgement.CDC labour-related corporate social responsibility is a paradox. The CDC has resorted to CSR decoupling in a bid to boost her image in public. Similarly, despite the low labour-related CSR scores, the CDC has recently built several modern buildings in Debuncha and Illoani to house workers and their families, and dilapidated buildings have also been renovated to give them a new look. Workers receive regular service training to improve their skills and prepare for promotion. However, the CDC should use effective corporate communication in a bid to set up a transparent dialogue with stakeholders that will foster a socially responsible course of action about how CSR issues in the company should be handled. If CDC establishes an effective 
communication strategy that connects management and employees on corporate social responsibility issues, it will benefit a lot. The management should clarify the role of employees in the implementation of corporate social responsibility through internal communication channels such as newspapers, emails, events and websites.

\section{REFERENCES}

[1] Reverte, C. (2009): Determinants of corporate social responsibility disclosure ratings by Spanish listed firms. Journal of Business Ethics, 88(2), 351-366.

[2] UN Global Compact-Accenture (2010): A new era of sustainability. Geraadpleegd op 7-6, 2016,https://www.unglobalcompact.org/docs/news_events/8.1/UNGC_Accenture_CEO_Study_2010.pdf

[3] Lee, M. P. (2008): Review of the theories of corporate social responsibility: Its evolutionary path and the road ahead. International Journal of Management Reviews, 10,1, 53-73.

[4] European Commission (2008): Restructuring in Europe. Brussels: European Commission.

[5] ESTER (2007): The international dimension of corporate social responsibility: ESTER final report. Bordeaux: ESTER.

[6] Visser, W. (2006b): 'Revisiting Carroll's CSR Pyramid. An African Perspective', in E. R. Pedersen and M. Huniche (eds.), Corporate Citizenship in Developing Countries (Copenhagen Business School Press, Copenhagen). pp. 29-56.

[7] Ndzi Ernestine (2016): Corporate social responsibility in Cameroon: The Hydro-electricity Sector.African Journal of Business Management,, ol. 10(7), pp. 151-161, 14

[8] Matten, D. and Moon, J. (2008): 'Implicit' and 'explicit' CSR: a conceptual framework for a comparative understanding of corporate social responsibility", Academy of Management Review, Vol. 33 No. 2, pp. 404-424.

[9] Palazzi, M. and Starcher, G. (1998): Corporate Social Responsibility and Business Success.Paris, European Bahá'í Business Forum, 1998

[10] Hejjas, K., Miller, G., Scarles, C. (2018): ““It's like Hating Puppies!” Employee Disengagement and Corporate Social Responsibility", Journal of Business Ethics, Vol. 157, No. 2, pp. 319-337.

[11] Bauman, C. W., Skitka, L. J. (2012): "Corporate social responsibility as a source of employee satisfaction", Research in Organizational Behavior, Vol. 32, pp. 63-86.

[12] Margolis, J.D. and Walsh, J.P. (2003): "Misery loves companies: rethinking social initiatives by business", Administrative Science Quarterly, Vol. 48 No. 2, pp. 268-305.

[13] Damnjanović, Milena (2019): Investing in Employees in Serbian Companies-Internal Dimension of CSR, In: Proceedings of the ENTRENOVA-Enterprise Research Innovation Conference, Rovinj, Croatia, 12-14 September 2019, IRENET - Society for Advancing Innovation and Research in Economy, Zagreb, Vol. 5, pp. 441-448

[14] GIZ. (2013): Shaping Corporate Social Responsibility in sub-Saharan Africa: Guidance Guidebook for MSP Facilitation. GIZ.

[15] Doshi, V., \&Khokle, P. (2012): An institutional perspective on corporate social responsibility. Vikalpa: The Journal for Decision Makers, 37(2), 98-102.

[16] DiMaggio, P. J., \& Powell, W. W. (2000): The iron cage revisited: Institutional isomorphism and collective rationality in organizational fields. In J. A. C. Baum \& F. Dobbin (Eds.), Economics meets sociology in strategic management (pp. 143-166). Advances in Strategic Management, vol. 17.

[17] Campbell, J.L. (2007): "Why would corporations behave in socially responsible ways? An institutional theory of corporate social responsibility", Academy of Management Review, Vol. 32 No. 3, pp. 946-967.

[18] DiMaggio, P.J. and Powell, W.W. (1983): "The iron cage revisited: institutional isomorphism and collective rationality in organizational fields", American Sociological Review, Vol. 48 No. 2, pp. 147-160.

[19] Aguilera, R.V., Rupp, D.E., Williams, C.A. and Ganapathi, J. (2007): "Putting the S back in corporate social responsibility: a multilevel theory of social change in organizations", Academy of Management Review, Vol. 32 No. 3, pp. 836-863.

[20] Visser, W. (2009): "Corporate social responsibility in developing countries", in Crane, A., McWilliams, A.,Matten, D., Moon, J. Donald S. and Siegel, D.S. (Eds), The Oxford Handbook of Corporate Social Responsibility, Oxford University Press, Oxford, pp. 473-502.

[21] Amaeshi, K.M., Adi, A.B.C., Amao, O.O. and Ogbechie, C. (2006): "Corporate social responsibility in Nigeria: western mimicry or indigenous influences”, Journal of Corporate Citizenship, Vol. 2006 No. 24, winter, pp. 83-98.

[22] Gulbrandsen, L.H. and Moe, A. (2007): "BP in Azerbaijan: a test case of the potential and limits of the CSR agenda?", Third World Quarterly, Vol. 28No. 4, pp. 813-830. 
[23] Fernando, S. and Lawrence, S. (2014): “A theoretical framework for CSR practices: integrating legitimacy theory, stakeholder theory and institutional theory", Journal of Theoretical Accounting Research, Vol. 10 No. 1, pp. 149-178.

[24] Freeman, R. Edward. (1984): Strategic Management: A Stakeholder Approach, Boston: Pitman Publishing Inc.

[25] Helmig, B., Spraul, K., \&Ingenhoff, D. (2016): Under Positive Pressure How Stakeholder Pressure Affects Corporate Social Responsibility Implementation. Business \& Society, 55(2), 151-187.

[26] Clarkson, M. E. (1995): A stakeholder framework for analysing and evaluating corporate social performance. Academy of Management Review, 20(1), 92-117.

[27] Jamali, D. (2007): "The case for strategic corporate social responsibility in developing countries",Business and Society Review, Vol. 112 No. 1, pp. 1-27.

[28] Frynas, J. G., \& Stephens, S. (2015): Political corporate social responsibility: Reviewing theories and setting new agendas. International Journal of Management Reviews, 17(4), 483-509.

[29] Frynas, J. G., \&Yamahaki, C. (2016): Corporate social responsibility: review and roadmap of theoretical perspectives. Business Ethics: A European Review, 25(3), 258-285.

[30] Surroca, J., Tribó, J. A., \& Zahra, S. A. (2013): Stakeholder pressure on MNEs and the transfer of socially irresponsible practices to subsidiaries. Academy of Management Journal,56(2), 549-572. doi:10.5465/amj.2010.0962

[31] Fongod, A. G. N., Veranso, M. C., Libalah, M. (2013): Identification and use of plants in treating infertility in human females in Fako Division, Cameroon, Global J Res. Med. Plants \&Indigen. Med., Volume 2(11): 724-737

[32] Moustakas, C. (1994): Phenomenological research methods. London, Sage

[33] Lofland, J., \& Lofland L. H. (2006): Analysing social settings: a guide to qualitative observation and analysis, Belmont, CA: Wadsworth/Thomson Learning.

[34] Yin, K. R. (2003): “Case Study Research: Design and Methods”, Sage Publications Inc., UK

[35] Konings, P. (1993a): Labour resistance in Cameroon: Managerial strategies and labour resistance in the agro-industrial plantations of the Cameroon Development Corporation. London: James Currey.

[36] Cameroon Development Corporation (2014): Cameroon Development Cooperation. Retrieved 2019, Jan. 08 from http://www.cdc-cameroon.com/.

[37] Obale, C.E. (2020): Privatisation of the Tole Tea Estate and the Brobon-Finex Saga: A Showcase of Corruption in a State Owned Corporation in Cameroon.International Journal of Research in Geography. vol 6, no. 2, 2020, pp. 27-42 doi: http://dx.doi.org/10.20431/2454-8685.0602004.

[38] Gamerschlag, R., Möller, K., \&Verbeeten, F. (2011): Determinants of voluntary CSR disclosure: empirical evidence from Germany. Review of Managerial Science, 5(2-3), 233-262.

[39] Brammer, S., \& Millington, A. (2008). Does it pay to be different? An analysis of the relationship between corporate social and financial performance. Strategic Management Journal, 29(12), 1325-1343.

[40] Hull, C. E., \& Rothenberg, S. (2008): Firm performance: The interactions of corporate social performance with innovation and industry differentiation. Strategic Management Journal, 29(7), 781-789.

[41] Hafsi, T., \&Turgut, G. (2013): Boardroom diversity and its effect on social performance: Conceptualization and empirical evidence. Journal of Business Ethics, 112(3), 463-479.

[42] Epale, S.J. (1985): Plantations and development in Western Cameroon. New York: Vantage Press

[43] Marano, V., \&Kostova, T. (2016). Unpacking the institutional complexity in adoption of CSR practices in multinational enterprises. Journal of Management Studies, 53(1), 28-54.

[44] Park, B. I., \& Ghauri, P. N. (2015): Determinants influencing CSR practices in small and medium sized MNE subsidiaries: A stakeholder perspective. Journal of World Business, 50(1), 192-204.

[45] Story, J., Story, J., Castanheira, F., Castanheira, F., Hartig, S., \& Hartig, S. (2016): Corporate social responsibility and organizational attractiveness: implications for talent management. Social Responsibility Journal, 12(3), 484-505.

[46] Greening, D. W., \& Turban, D. B. (2000): Corporate social performance as a competitive advantage in attracting a quality workforce. Business \& Society,39(3), 254-280.

[47] Backhaus, K. B., Stone, B. A., \&Heiner, K. (2002): Exploringthe relationship between corporate social performance and employer attractiveness. Business \& Society, 41(3), 292-318.

[48] Hopkins, M. (2003): The business case for CSR: where are we? International Journal of Business Performance Management, 5(2-3), 125-140.

[49] Godfrey, P. C., Merrill, C. B., \& Hansen, J. M. (2009): The relationship between corporate social responsibility and shareholder value: An empirical test of the risk management hypothesis. Strategic Management Journal, 30(4), 425-445. 
[50] Harjoto, M., \&Laksmana, I. (2016): The Impact of Corporate Social Responsibility on Risk Taking and Firm Value. Journal of Business Ethics, 1-21.

[51] Brammer, S., Millington, A., \&Rayton, B. (2007): The contribution of corporate social responsibility to organizational commitment. The International Journal of Human Resource Management, 18(10), 17011719.

[52] Lin-Hi, N., \& Blumberg, I. (2016): The Link Between (Not) Practicing CSR and Corporate Reputation: Psychological Foundations and Managerial Implications. Journal of Business Ethics, 1-14.

[53] Barney, J. B., \& Clark, D. N. (2007):Resource-based theory: Creating and sustaining competitive advantage. Oxford University Press on Demand.

[54] Cheng, B., Ioannou, I., \&Serafeim, G. (2014): Corporate social responsibility and access to finance. Strategic Management Journal, 35(1), 1-23.

[55] El Ghoul, S., Guedhami, O., Kwok, C. C., \& Mishra, D. R. (2011): Does corporate social responsibility affect the cost of capital?.Journal of Banking \& Finance, 35(9), 2388-2406.

[56] Banerjee, S. B. (2008): Corporate Social Responsibility: The Good, the Bad and the Ugly. Critical Sociology, 34, 51-79.

[57] Bice, S. J. (2013): Fortifying the Castle: Bridging Corporate Social Responsibility and Social Impact Assessment. Impact Assessment and Project Appraisal, 33, 2, 160-166.

[58] Skovgaard, J. (2012): Corporate Social Responsibility in the Danish shipping industry. Paper presented at the DRUID Academy Conference, Cambridge, UK. Retrieved from: http://druid8.sit.aau.dk/acc_papers/436055lixpr008mgnu655pfb6jhu.pdf

[59] Visser, W. (2014): The Age of Responsibility: CSR 2.0 and the New DNA of Business. London, UK: Wiley.

[60] Lyon, T. P., \& Montgomery, A. W. (2013). Tweet jacked: The Impact of Social Media on Corporate Green wash. Journal of Business Ethics, 118, 747-757.

[61] Petit jean, O. \& du Roy, I. (2015). COP21: Can Transitional Companies Save the Climate? Observatoire des Multinationales and Le Basic. UK: http://multinationales.org/IMG/pdf/abstract_uk.pdf

\section{AUTHORS' BIOGRAPHY}
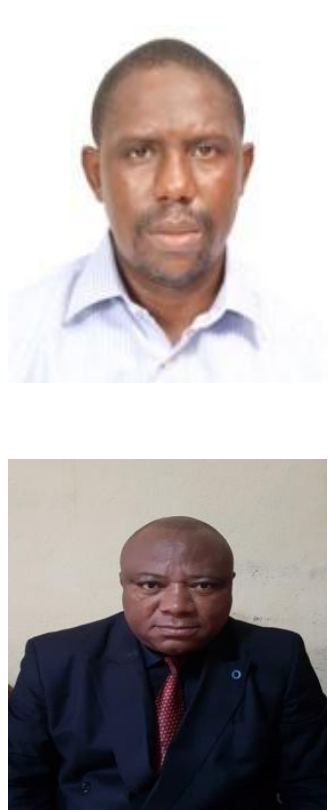

Clovis Ebot Obale, Ph.D. Candidate, with an M.Sc. in Human Geography from the University of Eastern Finland, an M.A in International Relations from the International Relations Institute of Cameroon (IRIC) and University of Ca'FoscariVenice- Italy,a Postgraduate Diploma in Education from the University of Yaounde I alongside a B.sc in Geography (Hons) from the University of Buea and a Diploma in Project Planning and Management from CITEC, Yaounde affiliated to the University of Bamenda.

Valentine Okale Dang, Deputy Director General, Credit Mutuel D'investissement du Cameroun (CREMINCAM), P.O box 3163 Yaoundé, Messa. B.Sc.(Hons)Banking and Finance, University of Buea, Harvard Kennedy School (HKS) Executive Education Alumni and a Certified Forensic Investigation Professional (CFIP) International Institute of Certified Forensic Investigation professional (IICFIP) Delaware USA.

Citation: Clovis Ebot Obale, Valentine Okale Dang, "Restructuring of CDC and Labour-Related CSR: Ambivalent Application of CSR in A State-Owned Enterprise." International Journal of Managerial Studies and Research (IJMSR), vol 9, no. 4, 2021, pp. 48-65. doi: https://doi.org/10.20431/2349-0349.0904006.

Copyright: (C) 2021 Authors. This is an open-access article distributed under the terms of the Creative Commons Attribution License, which permits unrestricted use, distribution, and reproduction in any medium, provided the original author and source are credited. 